\title{
TREN FOODIE: POTENSI STREET FOOD DI JAKARTA
}

\section{Tren Foodie: Potentials Of Street Food In Jakarta}

\author{
Douwes Lasmana, M.I.Kom \\ ${ }^{1}$ Hotel Business Program - Podomoro University, Let Jend. S. Parman Kav 28, 11470 \\ Diterima 13 Januari 2020 / Disetujui 16 Februari 2020
}

\begin{abstract}
Nowadays street food is playing an important role in tourism, food has become one of the main reason travelers fly hundreds and thousands of miles to another city or even country. Not only to the five-star restaurant but also street food vendors.

Promotion plays a very important role to broadcast the message from business owners to share their uniqueness and sales promotion. This will not be a problem for big players such as restaurant and hotels, but not for small and medium food vendors with limited capital. Foodie are the ones who are interested in specific cuisine or simply enjoy exploring food adventure has been effectively used to promote food and beverages product.

This research is aimed to analyze how foodies through Instagram promote street food business in Jakarta by increasing the relationship between brand and customers. Descriptive qualitative method is used in the research, while data is gathered from in depth interview with some foodie in Jakarta as well as street food vendor owners as well as observation.

The result explains that Instagram is used to broadcast their content. In some cases, foodies are hired to promote business although sometimes they have to pay for the food and beverages. Foodies are using their content mainly to share new trending vendors, or menu of certain vendors and at the same time increasing the quality of relationship between a brand and customer by increasing brand loyalty, brand awareness, brand engagement, and emotional attachments in order for a street food vendor to gain more customer.
\end{abstract}

Keywords: Foodie, Street Food, Instagram

\begin{abstract}
ABSTRAK
Saat ini street food memainkan peran penting dalam pariwisata, makanan telah menjadi salah satu alasan utama para pelancong terbang ratusan kilometer ke kota lain atau bahkan ke negara lain. Tidak hanya ke restoran berbintang lima tetapi juga pedagang kaki lima.

Promosi memainkan peran yang sangat penting untuk menyiarkan pesan dari pemilik bisnis untuk membagikan keunikan dan promosi penjualan mereka. Ini tidak akan menjadi masalah bagi pemain besar seperti restoran dan hotel, tetapi tidak untuk vendor makanan kecil dan menengah dengan modal terbatas. Foodie adalah orang-orang yang tertarik pada masakan tertentu atau hanya menikmati menjelajahi petualangan makanan yang telah secara efektif digunakan untuk mempromosikan produk makanan dan minuman.

Penelitian ini bertujuan untuk menganalisis bagaimana foodies melalui Instagram mempromosikan bisnis makanan jalanan di Jakarta dengan meningkatkan hubungan antara merek dan pelanggan. Metode kualitatif deskriptif digunakan dalam penelitian ini, sedangkan data dikumpulkan dari wawancara mendalam dengan beberapa foodie di Jakarta serta pemilik PKL serta observasi.

Hasilnya menjelaskan bahwa Instagram digunakan untuk menyiarkan konten mereka. Dalam beberapa kasus, foodies disewa untuk mempromosikan bisnis meskipun kadang-kadang mereka harus membayar makanan dan minuman.
\end{abstract}

\footnotetext{
*Korespondensi Penulis:

E-mail: douwes.lasmana@podomorouniversity.ac.id
} 
Foodies menggunakan konten mereka terutama untuk berbagi vendor tren baru, atau menu vendor tertentu dan pada saat yang sama meningkatkan kualitas hubungan antara merek dan pelanggan dengan meningkatkan loyalitas merek, kesadaran merek, keterlibatan merek, dan ikatan emosional agar penjual jajanan untuk mendapatkan lebih banyak pelanggan.

Kata kunci: Foodie, Makanan Jalanan, Instagram

\section{PENDAHULUAN}

\section{Latar Belakang}

Jakarta adalah melting pot untuk orangorang dari berbagai daerah di Indonesia. Dengan keragaman komunitas yang ada, kebutuhan akan makanan, baik makanan lokal, maupun internasional semakin meningkat. Ini bisa dilihat dari tumbuhnya bisnis kuliner di Jakarta, yang menjadikan Jakarta sebagai kota yang serba ada dalam hal makanan. Tingginya permintaan akan makanan tidak hanya terjadi di restoran mewah atau berbintang, tetapi restoran pinggir jalan, juga dikenal sebagai makanan jalanan atau street food, juga semakin lazim. Hampir setiap sudut jalan di Jakarta dipenuhi dengan pedagang kaki lima. Hal ini membuat kompetisi yang muncul juga menjadi sangat tinggi dan juga perubahan cepat yang melibatkan kebiasaan makan orang-orang serta gaya hidup mereka (Alfiero, 2017).

Tren menjadi wirausaha juga memainkan peran besar dalam pertumbuhan industri kuliner di Jakarta. Kaum muda yang memiliki pola pikir bahwa berbisnis di bidang kuliner adalah cara tercepat untuk menjadi wirausaha, menjadikan pertumbuhan usaha kecil di bidang kuliner yang akhirnya menjadi makanan jajanan menjadi sangat meriah. Modal awal yang rendah, risiko rendah dan kurangnya peraturan pemerintah tentang makanan jajanan telah membuat bisnis makanan jajanan berkembang pesat (streetfood.org.uk, 2019). Dalam persaingan di industri kuliner, banyak yang telah berhasil memenangkan hati orang banyak dan setelah sukses kemudian membuka beberapa cabang dan bahkan menjadikan bisnis itu menjadi waralaba yang menguntungkan bagi para investor. Tetapi banyak juga yang gagal dan akhirnya bangkrut.
Selain produk yang berkualitas baik, memiliki proposisi nilai yang jelas, tentu saja promosi berperan penting dalam keberhasilan bisnis kuliner. Apalagi masyarakat dihadapkan pada begitu banyak pilihan. Dalam hal ini strategi promosi yang kuat dengan modal besar tentu akan membantu bisnis untuk mendapatkan exposure yang lebih baik dibandingkan dengan pesaingnya. Bisnis makanan dan minuman besar dengan anggaran promosi dalam jumlah yang jugabbesar dapat dengan bebas mengoptimalkan semua alat komunikasi pemasaran terpadu, termasuk iklan TV yang membutuhkan banyak anggaran, tetapi sayangnya tidak untuk pedagang kaki lima yang memiliki anggaran sangat terbatas. Tentu saja, sangat sulit bagi pedagang kaki lima untuk dapat melakukan promosi berbayar melalui saluran iklan seperti iklan TV yang membutuhkan anggaran sangat tinggi.

\section{Identifikasi Masalah}

Di saat yang bersamaan, ada fenomena lainnya, di mana Instagram sekarang menjadi sangat populer dan digunakan sebagai sumber referensi untuk banyak hal, termasuk makanan dan minuman. Instagram juga digunakan sebagai album foto virtual karena memungkinkan pengguna untuk mengunggah gambar dan juga teks sebagai keterangan di bawahnya (Sheldon, 2016). Pengguna Instagram biasanya menggunakan Instagram untuk mencari referensi tentang barang atau layanan yang ingin mereka beli. Tidak jarang keputusan pembelian datang begitu saja ketika mereka melihat konten yang menginspirasi. Posting menarik juga pemicu pembelian impulsif. Ini menjadi lebih hidup karena kebiasaan anak muda yang selalu memposting foto makanan yang ingin mereka makan. Sekelompok orang yang memiliki minat mendalam pada masalah kuliner sering disebut sebagai 
Versi Online:

https://journal.ubm.ac.id/index.php/hospitality-pariwisata

DOI : http://dx.doi.org/10.30813/.v6i1.2025

Hasil Penelitian
Jurnal Hopitality dan Pariwisata

Vol.6 (No. 1 ) : no. 1 - no 55. Th. 2020

ISSN: 2442- 5222

e-ISSN : 2655-8165 pecinta kuliner (foodies). Foodies kini telah menjadi profesi yang populer. Para foodies menggunakan Instagram sebagai alat untuk menyalurkan hobi mereka serta berkomunikasi dengan penggemar mereka yang biasanya juga pecinta makanan, maka hal ini digunakan oleh pemilik bisnis sebagai peluang untuk mempromosikan produk dan layanan. Fenomena ini digunakan oleh pedagang street food. Para foodies digunakan oleh pedagang street food untuk mempromosikan produk mereka melalui akun Instagram mereka yang memiliki banyak pengikut.

Ada beberapa pendekatan untuk menjadi seorang foodie, ada yang menjadikan foodies sebagai sebuah profesi, biasanya foodies jenis ini telah menetapkan tarif bagi siapa saja yang ingin menggunakan layanan mereka. Biasanya metode ini disebut endorsement berbayar, tetapi ada juga yang menjalani profesi ini karena ini adalah hobi, jadi mereka tidak menetapkan tarif, hanya saja mereka tidak perlu membayar makanan atau minuman yang mereka pesan, bahkan ada pecinta kuliner yang juga memiliki banyak pengikut di Instagram di mana mereka membayar penuh untuk makanan dan minuman yang mereka pesan, dan terus memposting makanan dan minuman di Instagram mereka, sehingga pedagang makanan juga mendapat manfaat dari aktifitas ini.

\section{Tujuan dan Manfaat Penelitian}

Artikel ini akan membahas tentang bagaimana tujuan promosi dilakukan oleh foodies untuk mempromosikan bisnis street food di Jakarta, sehingga jenis bisnis kuliner ini dapat bertahan di tengah persaingan bisnis yang semakin ketat, melawan pesaing di berbagai skala, mulai dari sesama pedagang street food. , hingga pemain raksasa yang memiliki lebih banyak anggaran promosi.

\section{Makanan Jalanan dan Pecinta Makanan \\ Yang membedakan street food dari penjual makanan jenis lain bisa dilihat dari cara mereka dijual. Biasanya para pembeli makanan yang dijual oleh penjual street food, dapat langsung menikmati makanan tersebut, atau beberapa saat kemudian tanpa}

harus memasaknya lagi, atau makanan tersebut biasanya siap untuk dikonsumsi. Dijual di pinggir jalan atau di tempat umum lainnya (World Health Organization, 1996). Namun, kita tidak bisa menganggap remeh pedagang street food. Studi sebelumnya telah menyatakan bahwa makanan mungkin dapat menjadi faktor utama yang mengukur pemenuhan wisatawan tentang tujuan wisata (Smith et al., 2010), dan semakin tinggi tingkat pemenuhannya, semakin tinggi kemungkinan wisatawan untuk kembali ke tujuan wisata tersebut (Chen dan Tsai, 2007).

Foodies biasanya merupakan pelancong yang benar-benar tertarik menjelajahi segala sesuatu mengenai makanan. Makanan memainkan peran besar dalam suasana hati dan gairah mereka dan menjadi sumber sensasi mereka (Yeoman, 2012). Bagi para pecinta kuliner, makanan adalah alasan mereka untuk bersosialisasi dengan komunitas, dan untuk memperkaya pengalaman mereka, untuk mengekspresikan identitas unik mereka namun menambahkan kualitas hidup mereka juga (Yeoman, 2016). Cairns (2010) menyatakan bahwa foodies adalah orangorang yang memiliki minat dalam makan dan makanan tetapi tidak harus ahli dalam bidang tersebut. Dimana karakteristik foodies adalah mereka yang sangat antusias terhadap makanan, dan sangat bersemangat dalam mengeksplorasi tentang makanan.

\section{Promosi Melalui Media Sosial Instagram} Media sosial dengan semua pro dan kontranya menjadi topik yang menarik untuk dibahas. Ini telah menjadi bagian penting dari aktivitas kehidupan sehari-hari. Media sosial atau juga dikenal sebagai Situs Jejaring Sosial dirancang untuk kenyamanan pengguna untuk menemukan sesuatu yang berkaitan dengan minat atau kebutuhan mereka. Setiap Situs Jejaring Sosial digunakan untuk menjawab kebutuhan spesifik: Facebook digunakan untuk melihat pembaruan dari teman atau merk tertentu, dan Instagram untuk mereka yang suka mengabadikan, dan berbagi momen kehidupan sehari-hari mereka. (Blas et al., 2019). Fungsi Situs Jejaring Sosial telah 
Versi Online:

https://journal.ubm.ac.id/index.php/hospitality-pariwisata

DOI : http://dx.doi.org/10.30813/.v6i1.2025

Hasil Penelitian
Jurnal Hopitality dan Pariwisata

Vol.6 (No. 1) : no. 1 - no 55. Th. 2020

ISSN: 2442- 5222

e-ISSN : 2655-8165 berevolusi, dari tujuan pribadi ke tujuan profesional seperti promosi. Media sosial telah menjadi cara baru promosi yang memungkinkan pelanggan memilih, berbagi, dan menilai informasi yang ingin mereka konsumsi (Sheldon dan Bryant, 2016), dan sebagaimana dinyatakan oleh Jung (2017) media sosial memang telah digunakan sebagai alat iklan di era modern ini.

Blas (2019) menyatakan bahwa Situs Jejaring Sosial seperti Instagram digunakan untuk menciptakan dan mempertahankan hubungan pelanggan dan merek melalui peningkatan beberapa aspek:

- Loyalitas Merek

- Kesadaran Merek

- Keterlibatan Merek

- Keterikatan Emosional

Sementara penelitian sebelumnya menunjukkan bahwa Instagram sebagai situs jejaring sosial baru sangat kuat untuk meningkatkan reputasi merek dan menjangkau audiens yang lebih muda (Sashittal et al., 2016).

\section{METODOLOGI PENELITIAN}

Penelitian ini menggunakan metode deskriptif kualitatif dimana wawancara mendalam dengan beberapa pihak yang merupakan pemilik bisnis makanan dan street food serta observasi di akun Instagram untuk melihat konten dari posting dan juga isi dari komentar dan engagement di Instagram. Akun Instagram digunakan untuk mengumpulkan data dan informasi yang diperlukan untuk mengeksplorasi temuan.

Mr. Angky Tan (@angkytan) seorang foodie yang telah berkecimpung di industri ini selama 4 tahun dan telah menggunakan Instagram-nya untuk berbagi konten makanan telah diwawancarai. Akun @angkytan telah mengunggah 2.817 pos tentang makanan dan memiliki 34.100 pengikut. Selain itu Ms. Angelina sebagai salah satu pengikut setia@angkytan telah diwawancarai untuk melihat perspektif pelanggan dan terakhir Ms. Susan sebagai penjual street food yang telah berada di industri selama 3 tahun telah diwawancarai untuk mengumpulkan data darinsudut pandang penjual makanan.

Analisis data dalam penelitian ini dimulai dengan reduksi data, kemudian mengelompokkannya ke dalam kategori tertentu, kemudian pada langkah berikutnya, penulis membuat ringkasan deskriptif dan sistematis, kemudian selanjutnya, menarik kesimpulan berdasarkan data yang diperoleh dari berbagai sumber, kemudian mencari pendukung lainnya. Pada tahap ini, kesimpulan dibuat dengan data komparatif dari teori-teori tertentu (Cresswel, 1998). Proses ini dilakukan untuk melihat kebenaran dari hasil analisis yang akan menghasilkan kesimpulan yang valid.

\section{HASIL DAN PEMBAHASAN}

Foodie atau orang-orang yang menggemari makanan menggunakan Instagram tidak hanya untuk mengekspresikan diri mereka sendiri dan juga berbagi cerita harian mereka tentang makanan tetapi juga sebagai media promosi untuk berbagai penjual barang dan jasa. Kegiatan ini mendukung pengusaha, termasuk pengusaha street food yang memiliki anggaran promosi yang relatif lebih kecil dibandingkan dengan pengusaha besar yang mampu melakukan berbagai teknik promosi yang membutuhkan anggaran lebih besar. Akun Instagram dari foodie digunakan sebagai media untuk membangun komunikasi dan juga hubungan dengan audiens. Seperti yang dikatakan oleh Susan, yang merupakan penjual makanan jalanan dengan merek Nasi Pedas Oseng Juragan, mengatakan bahwa dia menggunakan Instagram untuk berkomunikasi dengan para calon pembeli, namun akun Instagram yang dia kelola tidak cukup untuk menjangkau terlalu banyak audiens, dia merasa jika ada foodieyang memposting foto makanan yang dia jual, itu akan sangat membantu karena pecinta makanan memiliki lebih banyak pengikut.

Instagram dianggap sebagai media yang ideal karena selain membutuhkan biaya yang relatif rendah, bahkan tanpa biaya, Instagram mampu menjangkau target audiens yang spesifik. Salah satu pengguna Ms. Instagram Angelina menyatakan bahwa ia benar-benar menggunakan Instagram 
Versi Online:

https://journal.ubm.ac.id/index.php/hospitality-pariwisata DOI : http://dx.doi.org/10.30813/.v6i1.2025

Hasil Penelitian
Jurnal Hopitality dan Pariwisata

Vol.6 (No. 1 ) : no. 1 - no 55. Th. 2020

ISSN: 2442- 5222

e-ISSN : 2655-8165 sebagai bahan referensi ketika ia mencari makanan. Biasanya dia mencari referensi di foodies yang dia ikuti di Instagram untuk mencari referensi dan kemudian memesan melalui Go Food (layanan pengiriman makanan online dengan ojek), selain itu dia juga menggunakan tagar untuk mencari jenis makanan menjadi inspirasi untuk memesan makanan.

Fitur-fitur di Instagram memang sangat mendukung untuk digunakan sebagai sumber referensi. Foto atau video yang disusun sedemikian rupa dibuat dengan tujuan untuk membangkitkan selera audiens. Dan foto dan video ini dapat dengan mudah dicari menggunakan tagar. tertentu (\#). Misalnya, seperti gambar di bawah ini.

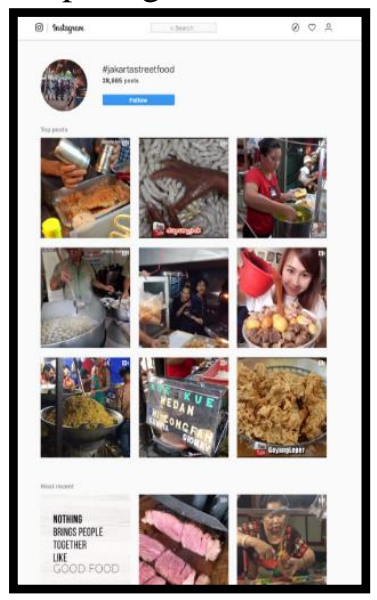

\section{Gambar 1. \\ Hasil Pencarian Instagram menggunakan \#jakartastreetfood}

Gambar di atas adalah hasil pencarian di Instagram menggunakan tagar \#jakartastreetfood. Dari pencarian ini saja, ada lebih dari 28.000 foto dan video yang terkait dengan makanan jalanan di Jakarta. Dari sekian banyak hasil pencarian tentunya, foto dan video dengan kualitas lebih baik akan lebih banyak dikunjungi. Di sinilah kemampuan orang yang memposting foto dan video memainkan peran penting. Foodies bersedia menghabiskan waktu mereka didedikasikan untuk membuat, memanipulasi dan menyiapkan konten untuk diunggah di Instagram mereka. Angky Tan sendiri mendedikasikan setidaknya 1 hingga 2 jam setiap hari untuk membuat konten yang menarik untuk Instagram-nya. Jadi, tidak mengherankan jika foodies ini memiliki banyak pengikut di Instagram dan Instagram mereka digunakan sebagai bahan referensi.

Banyak orang memposting foto atau video makanan secara acak dan kemudian menggunakan tagar tertentu, tetapi tidak mendapatkan likes di postingan mereka seperti para foodies. Ini bisa terjadi karena berbagai hal, misalnya orang-orang ini tidak memiliki pengikut yang cukup sehingga foto dan video yang mereka posting tidak terlalu terekspos, kualitas foto dan video tidak memadai sehingga tidak membangkitkan selera orang-orang yang melihat postingan dan juga persona orang yang tidak dikenal banyak orang sehingga orang enggan memberi like pada postingan tersebut. Persona memainkan peran penting dalam kinerja di Instagram. Ms Angelina mengakui bahwa sering menyukai posting yang diunggah oleh para foodies tanpa alasan yang jelas, sementara lebih ragu untuk memberikan like kepada orang-orang yang bukan foodie. Dia mengatakan ketika memberi like, dia merasa seperti dia lebih dekat dan bisa memberikan dukungan kepada foodie yang dia ikuti di Instagram. Seperti efek bola salju, semakin banyak orang yang menyukai posting tertentu, orang-orang yang memposting juga semakin populer di Instagram, dan semakin banyak orang populer akan mendapatkan lebih banyak like dan juga pengikut baru.

Artikel ini akan membahas tentang bagaimana foodies menggunakan Instagram yang digunakan oleh pemilik bisnis streetfood dalam membangun hubungan baik dengan pelanggan mereka.

Loyalitas Merek

Persaingan di bidang kuliner, khususnya street food dapat dianggap sebagai tantangan serius. Bukan hanya untuk menarik perhatian calon pelanggan dan membuat mereka ingin membeli produk yang dijual oleh pedagang street food, loyalitas konsumen tentu saja merupakan aspek yang sangat penting. Susan sebagai pemilik bisnis makanan jalanan mengatakan bahwa tidak hanya untuk mendapatkan pelanggan baru, dia berharap pelanggan lamanya terus 
Versi Online:

https://journal.ubm.ac.id/index.php/hospitality-pariwisata DOI : http://dx.doi.org/10.30813/.v6i1.2025

Hasil Penelitian
Jurnal Hopitality dan Pariwisata

Vol.6 (No. 1 ) : no. 1 - no 55. Th. 2020

ISSN: 2442- 5222

e-ISSN : 2655-8165 datang kembali. Susan juga mengatakan bahwa dengan kembalinya pelanggan ke tempatnya, dapat dipastikan bahwa pelanggan puas dengan kualitas produk dan layanan yang ditawarkan. Dari sana dia berharap bahwa pelanggannya dapat merekomendasikan bisnisnya kepada orang lain, dan seterusnya, seperti yang dikatakan oleh Shenx (2000) bahwa pelanggan setia tidak hanya menciptakan aliran dana jangka panjang ke perusahaan, tetapi juga untuk membawa pelanggan baru.

Dalam perspektif seorang foodie. Angky Tan merasa bahwa dia tidak pernah memikirkan perannya adalah untuk meningkatkan loyalitas konsumen terhadap suatu merek yang dia dukung. Dia merasa pekerjaannya selesai ketika dia memperkenalkan makanan kepada para pengikutnya dan mendapatkan berbagai komentar dan like dari para pengikut. Meskipun Angky mengatakan bahwa dia merasa bahagia dan bangga ketika makanan yang diunggah di Instagram memicu pelanggan untuk membeli produk, dan terlebih lagi menjadi berguna bagi pedagang street food, terutama jika akun Instagramnya membuat pelanggan menjadi pelanggan setia. Sementara Angelina mengatakan bahwa dia menjadi pelanggan setia makanan jalanan bukan karena posting di Instagram para foodies, tetapi karena kualitas produk, suasana, harga, dan tempat yang nyaman.

Kondisi ini wajar saja karena foodies yang fokus memposting konten tentang makanan selalu mengunggah foto makanan dari berbagai vendor, ini tidak mengindikasikan bahwa foodies memiliki keterikatan dengan satu vendor street food, sehingga para pengikut tidak akan melihat sikap foodie tersebu yang loyal kepada suatu merek, sehingga keputusan untuk menjadi pelanggan setia sepenuhnya ada di tangan pedagang street food, tergantung bagaimana barang dan jasa yang ditawarkan dapat memuaskan kebutuhan konsumen dan tentu saja bisa menjadi unik dibandingkan dengan pesaing yang menjual produk serupa.

\section{Kesadaran Merek}

Pecinta makanan dengan jumlah pengikut yang besar di Instagram akan menjadi target oleh pedagang street food. Pemain di sektor kuliner yang tidak memiliki anggaran besar tentu harus melakukan promosi besar agar dapat menonjol bagi pesaing mereka. Keller (2009) mengatakan bahwa media sosial dapat menjangkau lebih banyak khalayak daripada media tradisional seperti $\mathrm{TV}$, radio dan media cetak. Ini terjadi karena beberapa fitur di media sosial, misalnya Instagram yang memungkinkan pemasar untuk menargetkan pasar lebih khusus dan dengan jumlah yang hampir sama dengan jangkauan media tradisional yang masif namun tidak terlalu tertarget.

Apalagi jika kita berbicara tentang akun Instagram milik foodies. Angky memiliki lebih dari 18.000 pengikut di Instagram-nya, yang semuanya pasti menjadi penggemar makanan karena hampir 100\% dari isi Instagram Angky, @angkytan adalah foto dan video yang terkait dengan semua jenis makanan yang telah dikuratori secara independent, secara pribadi oleh Angky sendiri. Dengan kata lain, ada potensi untuk memperkenalkan produk makanan baru kepada 18.000 lebih banyak pengikut Angky yang merupakan penggemar makanan.

Susan mengaku sangat menggunakan bantuan para foodies dalam memperkenalkan menu baru yang akan diluncurkan di warung makannya. Dia mengakui bahwa setiap kali produk baru diunggah oleh seorang foodie, dia biasanya sering mendapatkan lebih banyak pelanggan baru yang ingin mencoba menu baru dan mereka biasanya mengatakan bahwa mereka mendapatkan informasi tentang menu baru tersebut dari foodie yang mereka ikuti di Instagram.

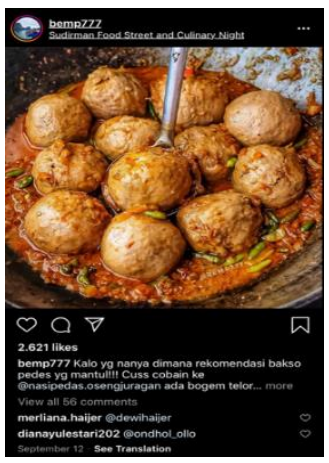

Gambar 2 
Versi Online:

https://journal.ubm.ac.id/index.php/hospitality-pariwisata DOI : http://dx.doi.org/10.30813/.v6i1.2025

Hasil Penelitian
Jurnal Hopitality dan Pariwisata

Vol.6 (No. 1 ) : no. 1 - no 55. Th. 2020

ISSN: 2442- 5222

e-ISSN : 2655-8165

\section{Street Food di Instagram Foodie}

Gambar 2 menggambarkan salah satu menu baru yang diluncurkan pada September 2018 oleh Nasi Pedas Oseng Juragan yang dikelola oleh Susan, yang diunggah oleh seorang foodie dengan akun Instagram @ bemp777. Foodie ini memiliki lebih dari 164.000 pengikut, dan dari sekian banyak pengikut, 2.621 pengikut memberikan like dan 56 komentar dalam postingnya yang diunggah tentang menu baru yang dijual di Nasi Pedas Oseng Juragan. Selain membuat para pengikut sadar akan menu baru, bagi pengikut yang belum pernah mengenal Nasi Pedas Oseng Juragam, tentu saja menjadi sadar akan keberadaan PKL yang dimiliki oleh Susan.

\section{Keterlibatan Merek}

Salah satu fitur di media sosial di mana audiens dapat mengambil bagian secara langsung dalam promosi. Berbeda dengan media tradisional yang satu arah, media sosial termasuk Instagram menawarkan fitur yang memungkinkan audiens untuk berinteraksi dan berkontribusi dalam promosi. Konsumen juga semakin suka dan ingin terlibat langsung dalam proses promosi dan tentunya juga menentukan identitas dan citra suatu merek (Doorn et al. 2010).

Hal ini membuat pemasar yang menggunakan Instagram sebagai media promosi harus lebih berhati-hati karena akses terbuka bagi audiens untuk berkontribusi dapat menjadi "bumerang" bagi pemasar. Di Instagram, audiens dapat berinteraksi hanya dengan memberikan like yang memiliki dampak dan risiko minimal, fitur share yang memungkinkan audiens untuk berbagi posting yang ia suka dan tidak suka kepada pengguna Instagram lain, dan fitur komentar yang berisiko, di mana audiens dapat dengan bebas mengekspresikan pendapat mereka, dan mengekspresikan ketidaksetujuan mereka terhadap isi posting tertentu. Tetapi di sisi lain, ketika audiens mengomentari pos secara positif, maka, pada saat yang sama mereka juga memberikan kontribusi positif dalam membangun citra merek yang diwakili melalui posting tersebut.
Kualitas gambar dalam bentuk foto dan video yang dibuat sedemikian rupa sehingga terlihat begitu menarik tentu akan mendapatkan lebih banyak engagement. Selain itu, selain gambar-gambar menarik yang terlihat menggoda, biasanya para pecinta kuliner juga menggunakan deskripsi yang juga sangat mengundang, sehingga pengikut mereka semakin tertarik mencoba makanan yang direkomendasikan melalui pos.

Brand Engagement bukan hanya fitur di media sosial, tetapi sebagai tanda di mana ada ikatan emosional antara merek dan konsumennya, ini menunjukkan minat seseorang pada merek tertentu. Instagram dengan fitur sejenisnya mengarahkan pemirsanya untuk memberikan respons positif. Saat ini Instagram tidak memiliki fitur "dislike" sehingga dapat disimpulkan bahwa semakin besar jumlah like yang diperoleh melalui pos, semakin banyak konten yang disukai posting oleh penonton. Namun di kolom komentar, audiens dapat mengekspresikan pendapat mereka secara lebih bebas, serta memancing pendapat lain dari pengguna Instagram lainnya. Isi komentar di Instagram dapat digunakan sebagai bahan evaluasi untuk pemasar yang menggunakan Instagram sebagai media promosi. Seperti yang dikatakan oleh Susan, pemilik Nasi Pedas Oseng Juragan yang sering menggunakan Instagram sebagai bahan evaluasi, dari kolom komentar di akun Instagram-nya sendiri dan dari kolom komentar di posting para foodies yang mengunggah konten makanan yang ia jual. Sebelum adanya media sosial, keterlibatan dilakukan dengan menggunakan metode tradisional. Evaluasi pada masa itu juga menggunakan metode tradisional, seperti kuesioner atau meminta pelanggan secara langsung. Hasil dari metode ini mungkin tidak akurat karena kejujuran dari pelanggan yang memberikan tanggapan belum tentu merupakan pendapat yang jujur. Namun melalui media sosial, audiens biasanya memberikan umpan balik yang jujur, kadang tanpa harus diminta dan tanpa paksaan, sehingga umpan balik yang diberikan mungkin lebih jujur. 


\section{Keterikatan Emosional}

Keterikatan emosional pelanggan adalah dasar dari hubungan antara merek dan pelanggan (Orth et al., 2010). Dalam hal promosi street food melalui Instagram, yang dikelola oleh foodies, pelanggan hampir tidak memiliki ikatan emosional dengan merek atau ulasan mak oleh foodies. Susan, sebagai pemilik bisnis street food, mengatakan bahwa untuk membangun keterikatan emosional dengan pelanggannya, dia harus berusaha sendiri untuk dapat secara pribadi mendekati para pelanggan ini. Pelanggan yang sudah menyukai makanan yang ditawarkan cenderung memiliki minat untuk kembali, dan ketika menu baru ditawarkan, mereka biasanya mau mencoba makanan baru. Pada titik ini, Susan mulai mengembangkan strategi untuk membangun hubungan yang lebih dekat dengan pelanggannya, sehingga pendekatan pribadi biasanya diambil, untuk mendapatkan ikatan emosional dari pelanggan. Susan juga menyatakan keterikatan emosional tidak diperoleh dari pos yang diposting di Instagram.

Di sisi lain, keterikatan emosional terjadi pada khalayak media sosial, yang mungkin pelanggan street food terhadap para foodies yang mengunggah foto di Instagram. Angelina mengakui, dia sering ingin mencoba makanan yang diunggah oleh para foodies yang diikuti di Instagram, kemudian memposting foto makanan yang direkomendasikan oleh para foodies ini dan kemudian melakukan tag para pecinta foodies. Ini juga secara tidak langsung mendukung tujuan para pedagang jajanan untuk meningkatkan awareness masyarakat terhadap bisnis mereka.

Keterikatan emosional adalah bentuk kesetiaan pelanggan yang lebih tinggi, keterikatan emosional melibatkan perasaan pribadi pelanggan yang muncul ketika berinteraksi dengan merek dalam hal ini penjual makanan streetfood, berbeda dengan loyalitas pelanggan yang muncul atas dasar untuk memenuhi kebutuhan tertentu dan mencapai harapan tertentu dari pembelian sebuah produk.

\section{SIMPULAN}

Berdasarkan uraian berbagai hal di atas, dapat disimpulkan bahwa, meskipun persaingan ketat dalam industri street food di Jakarta, industri ini akan terus tumbuh karena tingginya kebutuhan dan minat masyarakat. Salah satu strategi untuk dapat bertahan dalam kompetisi adalah menggunakan Foodies yang menggunakan Instagram sebagai alat promosi.

Promosi oleh foodies melalui Instagram dapat digunakan untuk meningkatkan hubungan baik antara bisnis street food dan pelanggan mereka yang dilakukan dengan tujuan memperluas kesadaran dan juga meningkatkan jumlah pelanggan baru.

Perbaikan dalam berbagai aspek harus dilakukan untuk meningkatkan hubungan yang baik antara pelanggan dan pedagang street food termasuk loyalitas merek, kesadaran merek, keterlibatan merek, dan juga keterikatan emosional pelanggan. Namun, kinerja dan upaya pribadi masingmasing pemilik usaha yang kemudian dapat meningkatkan status pelanggan yang masih asing dengan produk tersebut untuk menjadi agen promosi dari merk tersebut.

Artikel ini dapat bermanfaat sebagai masukan bagi pemilik bisnis street food di Jakarta untuk lebih memahami peran foodies dalam mengembangkan bisnis mereka sehingga mereka dapat lebih sukses dalam memenangkan persaingan.

\section{DAFTAR PUSTAKA}

Alfiero, S., Lo Giudice, A. and Bonadonna, A. (2017), "Street food and innovation: the food truck phenomenon", British Food Journal, Vol. 119 No. 11, pp. 24622476. https://doi.org/10.1108/BFJ03-2017-0179.

Cairns, K., Johnston, J., \& Baumann, S. (2010). Caring About Food: Doing Gender in the Foodie Kitchen. Gender \& Society, 24(5), 591-615. 
https://doi.org/10.1177/0891243210 383419.

Chen, C.F. and Tsai, D.C. (2007), "How destination image and evaluative factors affect behavioral intentions?", Tourism Management, Vol. 2 No. 4, pp. 1115-22.

Cresswel, J.W. 1998. Qualitative Inquiry and Research Design: Choosing Among Five Traditions. California:SAGE Publications, Inc.

Doorn, J.V. et al., 2010. Customer Engagement Behaviour: Theoretical Foundations and Research Directions. Journal of Service Research, 13(3), pp.253-266. http://www.streetfood.org.uk/whatis-street-food.html (accessed on October 2nd 2019).

Jerome B. Kernan, Montrose S. Sommers, Meaning, Value, and the Theory of Promotion, Journal Communication, Volume 17, Issue 2, June 1967, Pages 109135, https://doi.org/10.1111/j.14602466.1967.tb01168.x.

Keller, K.L. (2009), "Building strong brands in a modern marketing communication environment", Journal of Marketing Communication, Vol. 15 Nos 2/3, pp. 139-55.

Orth, U.R., Limon, Y. and Rose, G. (2010), "Store-evoked affect, personalities, and consumer emotional attachments to brands", Journal of Business Research, Vol. 63 No. 11, pp. 1202-1208.

Sanz-Blas, S., Buzova, D. and MiquelRomero, M. (2019), "From Instagram overuse to instastress and emotional fatigue: the mediation of addiction", Spanish Journal of Marketing - ESIC, Vol. 23 No. 2, pp. $143-$
161. https://doi.org/10.1108/SJME12-2018-0059

Sashittal, H.C., DeMar, M. and Jassawalla, A.R. (2016), "Building acquaintance brands via snapchat for the college student market", Business Horizons, Vol. 59 No. 2, pp. 193-204.

Sheldon, P. and Bryant, K. (2016), "Instagram: motives for its use and relationship to narcissism and contextual age", Computers in Human Behavior, Vol. 58, pp. 8997.

Shenx, Tan K.C. and M. Xie, 2000. Innovative product development using Kano's model and QFD European J. Innovation Management, 3(2): 91-99.

Smith, S., Costello, C. and Muenchen, R.A. (2010), "Influence of push and pull motivations on satisfaction and behavioral intentions within a culinary tourism event", Journal of Quality Assurance in Hospitality \& Tourism, Vol. 11 No. 1, pp. 17-35.

World Health Organization (1996), "Essential safety requirements for street-vended foods", available at: www.who.int/foodsafety/publicatio ns/street-vended-food/en/ (accessed 12 September 2019).

Yeoman, I. (2012), 2050: Tomorrows Tourism, Channel View, Bristol.

Yeoman, I. and McMahon-Beatte, U. (2016), "The future of food tourism", Journal of Tourism Futures, Vol. 2 No. 1, pp. 95-98. 